\title{
The British Postgraduate Medical School
}

TONDON has a supply of clinical material1 that is, cases of sickness and diseasealmost unique in amount and variety, which should be available for teaching and research. Some of this material is utilised by the medical schools in their attached hospitals for the training of their undergraduate students, whom they must in the main serve, and their facilities for the additional training of the postgraduate student are necessarily limited. In fact, London has hitherto lacked an organisation for postgraduation study comparable to the continental centres, such as Vienna. London's wealth of clinical material should be available for the provision of courses of advanced instruction for qualified doctors resident in Great Britain, in the Empire beyond the seas, and abroad, who wish to refresh or extend their knowledge, or to obtain the latest information on new developments in medicine, surgery and obstetrics.

Attempts have been made in the past to institute courses of postgraduation study. In the closing years of last century, the Medical Graduates College and Polyclinic, organised in the main by Sir Jonathan Hutchinson, gave courses of systematic lectures in various branches of medicine, in association with classes and clinics in certain special hospitals and medical schools, but it could not provide that regular attendance at in- and out-patient departments which is one of the principal requirements of the general practitioner and of the specialised postgraduate student. Postgraduate courses of instruction have also been organised by some of London's hospitals which have no medical school attached, for example, the West London, Hammersmith, the Prince of Wales, Tottenham, and the Seamen's Hospital, Greenwich.

Another organisation which has done, and is doing, much good work in the direction of postgraduation study, is the Fellowship of Medicine and Post-graduate Medical Association, with which the name of the late Sir William Osler should be remembered. But its scope is limited much in the same way as in the Polyclinic.

The serious consideration of the problem of a postgraduate medical college dates back to 1921 , when Dr. Addison, then Minister of Health, at the suggestion of the University Grants Committee, formed a Committee under the chairmanship of the Earl of Athlone to consider, among other matters, the provision in London of a school with hospital attached to be devoted to postgraduate instruction in medicine, and of an institute for instruction in public health subjects. Largely by the aid of a very generous grant from the Rockefeller Foundation, the last-named institution was the first to be established, and the buildings of the London School of Hygiene and Tropical Medicine were opened in July, 1929.

The other objective of the Athlone Committee still remained to be secured, but the post-War depression had already begun and the scheme remained in abeyance for a time. Then $\mathrm{Mr}$. Neville Chamberlain set up another committee, the terms of reference of which were "to draw up a practicable scheme of postgraduate medical education centred in London". This Committee surveyed the situation, and came to the conclusion that it was impracticable to establish a new school with hospital attached, or to associate the new school with any existing teaching hospital. But fortunately, by the passing of the Local Government Act of March, 1929, between twenty and thirty municipal general hospitals, formerly under the Poor Law, came under the control of the London County Council, and a scheme of associating the proposed postgraduate medical school with one of these institutions was then explored. With the full co-operation of the London County Council, the unanimous conclusion was finally reached that the conversion of the hospital in Ducane Road, Hammersmith, was the best solution of the problem. Here there were 400 beds housed in a building no part of which was more than twenty-five years old, and which had been described as "exceptionally good and well designed for the purposes of a hospital dealing with the acutely sick".

In April, 1930, Mr. Greenwood, then Minister of Health, announced the Government's acceptance of the Committee's recommendations, and its willingness to contribute a sum up to $£ 250,000$ for building and equipping the School, together with annual grants for maintenance through the University of London. Following the recommendations of another Committee over which Lord Chelmsford presided, a Royal Charter was granted to the School on July 10, 1931. Unfortunately, shortly afterwards the financial crisis developed and jeopardised the whole scheme, but after serious consideration the Government of the day decided that it was against the public interest to postpone the scheme indefinitely, and offered to make a grant not exceeding $£ 100,000$, and the L.C.C. agreed to expend a similar sum towards adaptation of the existing Hospital for the purposes of the School.

Financial reasons again delayed the commencement of building, but the foundation stone was laid by Mr. Neville Chamberlain in July last year, and substantial progress has since been made in the adaptation of the existing buildings and provision of the new ones required.

The L.C.C. is providing, on the hospital side, new blocks for midwifery cases, for out-patients, and for casualty departments, while the School buildings will consist mainly of laboratories, lecture theatres, and accommodation (non-residential) for the teachers and students. The Dean of the School, Dr. MacKeith, has recently issued a circular descriptive of the general plan of the buildings and of the accommodation provided. 
The University of London has also recently 'recognised' the new institution as a 'school' of the University, and four chairs have now been advertised, in medicine, surgery, obstetrics and gynæcology, and pathology. Presumably, assistants will also be needed for each unit, and it may be anticipated that courses will also be delivered from time to time by eminent physicians, surgeons and others not permanently attached to the School.
In addition, the courses in present postgraduate centres will still be made use of so far as possible.

Thus, after many vicissitudes, a postgraduate medical school worthy of the great Metropolis has come into being, which it may be anticipated will in the future raise the standard of professional skill among the great body of medical practitioners, and will advance the progress of medical science by research carried out within its walls.

\section{Obituary}

\section{Prof. Camille Matignon}

$\mathrm{A}^{\mathrm{B}}$ RTHËME CAMILLE MATIGNON, president of the French Chemical Society, who died suddenly in Paris on March 18, was a leading figure in pure chemistry and a great exponent of chemical technology. Matignon was born at Saint Mauriceaux-Riches-Hommes, Yonne, on January 3, 1867, and entered the Ecole Normale, Paris, in 1886; three years later he became assistant to Berthelot at the Collège de France and commenced a long series of original contributions to our knowledge of thermochemistry. After spending five years at the University of Lille as lecturer and professor, he was appointed as a temporary professor at the Collège de France in 1902, a supplementary professor in 1903 and, on the death of Berthelot, became professor of inorganic chemistry in 1908, holding this post until his death.

Matignon early concerned himself with the great problem of the fixation of atmospheric nitrogen and the synthetic production of ammonia; he studied the direct combination of many of the metals with nitrogen, showing that zinc dust always contains zine nitride, and preparing the nitrides of a number of the rare earth metals. Certain of the nitrides, such as those of silicon and aluminium, were probably formed during the cooling of the earth and, by the action of water vapour, gave ammonia, the first form in which nitrogen became available for assimilation by plant life. Matignon maintained that the increased use of artificial nitrogenous fertilisers was essential to the development of French agriculture; he followed up the advocacy of this principle by working out methods for the economic production of phosphates and potassium salts for use as manures.

With the aid of the calorimetric bomb, Matignon determined the heats of combustion of a long series of substances and, since many of these were closely related organic compounds, he was able to deduce a number of interesting generalities from the heats of formation. His more extended studies of the part played by heat in chemical reactions led him to the statement of an empirical law of thermodynamics which Nernst termed the 'Le Chatelier-Matignon rule'. This states that for gaseous equilibria in which one gaseous and one or more solid phases are concerned (sublimation of solids, dissociation of calcium carbonate, etc.), the relation $Q / T=32$ holds approximately in all cases, $Q$ being the heat evolved at constant pressure and $T$ the absolute temperature at which the gaseous pressure attains one atmosphere. This empirical law is an extension to chemical dissociation of Trouton's law concerning heats of vaporisation. The Le Chatelier-Matignon rule can be stated in several ways and may be used to foretell whether certain reactions can take place and whether they are reversible. Thus, it was foreseen that hydrogen sulphide should react with potassium carbonate, but not with sodium carbonate at the ordinary temperature; these deductions were verified by experiment. Matignon's achievements in these and many other fields were recognised by his election to the Institut de France in 1926.

Matignon was an eloquent speaker and wrote in a lucid, convincing style. He assumed the editorship of the Journal of the French Society of Industrial Chemistry at its inception in 1918, and the editorial which he wrote each month until the end of his life was read with interest by the whole chemical world ; the last of these articles-on the fiftieth anniversary of the death of Dumas-appears in the March number of Chimie et Industrie which was published a few days ago. Matignon's striking personality and his gay, vivacious enthusiasm made him a notable figure. He did much to promote the re-establishment of those normal relations between scientific men throughout the world which had been so rudely shattered by the War; he had many friends far outside his own country who will remember him with respect and affection.

W. J. Pope.

\section{Mr. E. G. B. Meade-Waldo}

IT is with great regret that we have to record the death of Mr. Edmund Gustavus Bloomfield Meade-Waldo, of Stonewall Park, Chiddingstone, Kent, who died on February 24, aged seventynine years. Only son of Mr. Edmund Waldo Meade-Waldo, of Hever Castle and Stonewall Park, he was born at Holly Brook, Co. Cork, on February 8, 1855, and educated at Eton and Magdalene College, Cambridge. His room at Eton was a menagerie of wild animals, and rumour has it that, while at Eton, his overpowering ambition was to kill one of the red-deer in Windsor forest, and that this ambition was fulfilled. In 1880 he married Ada Coralie, a daughter of the 